\title{
Mobile Application Design for Ordering Clean Water Using UCD Method in Indonesia
}

\author{
https://doi.org/10.3991/ijim.v15i02.11313 \\ Dominikus Boli Watomakin, Baltra Agusti Pramajuri, Suyoto ( $\square$ ) \\ Universitas Atma Jaya Yogyakarta, Yogyakarta, Indonesia \\ suyotodstaff.uajy.ac.id
}

\begin{abstract}
Clean water is an essential basic requirement for humans. In eastern Indonesia, especially the provinces of East Nusa Tenggara (NTT), Maluku, and Southeast Sulawesi, the need for clean water is quite urgent. The socio-cultural conditions, geographical conditions, low rainfall levels, and the distribution of freshwater from the Regional Water Company (PDAM) is still not right. In the three provinces, communities utilize clean water buying and selling services using tank cars to fulfill their daily needs for clean water in reservoirs and water tanks. Orders still use telephone or SMS, so it is slower. Thus, the design of mobile ordering applications for clean water was proposed in this study and was named Go-Water. With the Go-Water app, users order clean water by choosing the closest shelter model and driver, and then the order is forwarded to the driver for processing. The User-Centered Design (UCD) method use for GoWater application design. The Go-Water application help users to order clean water quickly and help improve business quality for service providers. The usability perspective analysis results on the Go-Water application design obtained an average percentage of $83 \%$. This study's contribution is the design of the proposed mobile application centered on the user. Previously, there was no system for ordering 5,000 liters and 6,000 liters of clean water using a tank car. The price offered was more beneficial for both parties.
\end{abstract}

Keywords-Water scarcity, clean water, mobile application, UCD

\section{Introduction}

Clean water is a very urgent daily necessity in parts of Indonesia, especially parts of eastern Indonesia called the province of East Nusa Tenggara, known as NTT [1], Moluccas province, and Southeast Sulawesi province. Communities in the three regions are still having difficulty obtaining clean water for various purposes, such as bathing, washing, drinking, etc. Water Supply System (SPAM) service in Indonesia (2017) for three regions that are among the lowest, i.e., NTT amounting to $12.94 \%$ from 4,683,827 people, Moluccas amounted to $16.93 \%$ from 1,533,506 people, and Southeast Sulawesi was $13.96 \%$ from 2,232,586 people [2]. In NTT, the difficulties of clean water such as socio-cultural conditions, geographical conditions, relatively short rainfall levels between two to three months in one year, and water distribution from 
Regional Water Supply Companies known as PDAM have not been useful [3]. Also, the community must be burdened with bills every month even though water distribution is not smooth.

The three provinces' communities meet their daily clean water needs by taking other choices, namely buying clean water in several sheltered drinks of water buying and selling service providers that use tankers with capacities of 5000 liters and 6000 liters. The freshwater buying and marketing service providers can meet the community's needs, who have a clean water reservoir model with a capacity of 5000 liters or 6000 liters, and a water reservoir storage model with a total of 5300 liters. The community prefers this alternative because the available water is always compared to the PDAM. Seeing the business potential of clean water buying and selling service providers using tank cars, some businessmen glanced at and exploited this potential to gain profits and, at the same time, help the community. Thus, making providers of clean water buying and selling services in the three provinces quite developed.

People who want to buy clean water first order to purchase water supply service providers via telephone or SMS. Then the water ordered is following the capacity requirements available to the community. This running system has not been maximized for both the buyer and the service provider. For the buyer, the time needed to wait for water is very long. For service providers, because many who order have not been able to divide the schedule to distribute water to the community faster, the service provider will have difficulty delivering water if the destination address is unknown.

The rapid development of technology from day to day is no exception to the development of smartphone technology. According to Hootsuite data, as of January 2019, unique mobile users in Indonesia have touched 335.5 million. This data shows that smartphones are technologies that cannot be separated from human life because it facilitates various daily activities of its users [4]. One thing that helps users is doing business activities, as in this case, is ordering clean water for areas that lack water. In smartphone technology, there is a vital aspect, namely the interface of the system being built. This study uses the User-Centered Design (UCD) method, which is more focused on the user interface that is easy to use and involves users from the beginning of the design process to completion [5].

A Mobile water-based ordering system using UCD, called Go-Water, significantly helps users conduct clean water buying and selling activities. The community's problems in obtaining freshwater information are made more accessible. People are more satisfied in knowing the price in real-time-a display suits customers and clean water services providers. The buyer only should choose and process the system to the service provider so that distributing clean water to the buyer is faster.

\section{Literature Review and Related Works}

From several previous studies, there were several papers relating to the design of mobile-based applications, including S. Atawneh (2019), which made an application for domestic delivery of products door-to-door [6]. Whereas the research written by S. 
Duraisamy and J. U. Abuhuraira (2018) is designing a mobile application for booking bus tickets to replace the manual ordering system for which purchases are made at counters [7]. Apart from booking bus tickets, there are also mobile ticket-based ticket bookings [8].

Another mobile application design paper is designing a mobile application to provide information on the shortest path in food delivery to save fuel and optimize shipping [9]. X. Zhang and J. Bi (2018) designed a mobile application for learning English in universities [10].

Furthermore, WD Raharjo and A. Wardhana (2018) discuss the restaurant mustache's food ordering system using smartphones or tablets. The design makes it easier for customers to order food menus when arriving at the restaurant without waiting for the waiter. The system also facilitates the servant without having to meet customers one by one [11].

In the mobile application, the system's interface design, especially those based on the users' needs. As done by N. Jochems (2016), this study summarises a variety of methods integrated into a user-centered design approach to develop design concepts for tablet computers, focusing on the needs and desires of the elderly [12].

The User-Centered Design (UCD) method has been used in the software industry and is taught to software developers to meet various user needs [13]. The UCD method has also been used in the health sector, such as research by R. Schnall et al. (2016), who designed the application of mHealth [14]. Whereas the research of M. Maher et al. (2016) and L. Runaas et al. (2017), it discusses developing tools that allow users in the real world, the daily practice of Hematopoietic Cell Transplantation (HCT) patients and caregivers (users) in hospitalization settings [15] [16].

Research by G. Tanaksaranond (2018) develops a mobile-based application that helps users to provide a path to a parking lot in a mass transit station to avoid congestion in the city of Sathorn, Bangkok. Researchers use UCD and User Experience to design the application so that it is easy to understand and operate by the user [17]. Whereas in the research by Muljono et al. (2016), it was to build a BacaBicara, an Indonesian language was learning media to help deaf and half-hearing people. Learning media created using the UCD concept to fit the needs of users [18]. Another study about interface design was done by P. W. T. Maharani Maulydia and Arianis Chan (2017). They conducted a comparison test of the experience of Go-Jek and Grab application users [19].

For the comparison paper in seeing the improvement part of each document, L. A. Wardana et al. (2017) discusses the design of mobile counseling applications for marriage preparation using UCD. The improvement room presented is usability with five stages of obtaining the final system design, including identifying needs, determining users, determining requirements, designing solutions, evaluating models, and implementing models. All of these stages are made using the wireframe method [20]. The same is the case with research by Amir Dirin and Marko Nieminen (2015). They used UCD to design mobile learning applications using three evaluation processes: Usability assessment, user assessment, and qualitative research [21].

Another comparative paper is R. Dermawi et al. (2018), which makes UCD-based Communication Board (CB) applications for deaf people to be able to communicate 
with ordinary people [22]. Another comparison paper presented by R. Roth et al. (2015) built the GeoVISTA CrimeViz application or GIS-based criminal mapping using the UCD concept. The application interface is improved using three stages: User, utility, and usability [23].

Y. Arifin et al. (2019) researched gamification for the ancient kingdom of Nusantara with a User-Centered Design approach. The researcher collected data from questionnaires and surveys. The gamification method results were suitable for learning the history of ancient kingdoms in Indonesia [24].

From various research studies and the results of comparison of updates from several papers relating to mobile application-based ordering and inquiry associated with UCD, the researchers concluded the renewal in this study to build mobile-based clean water ordering application design using UCD. Thus, the application design offered will significantly help users who previously relied on a prolonged system, where the stages in UCD are used, namely user requirements, design evaluation, and user usability analysis, so that the system is easier to understand in its operation.

\section{$3 \quad$ Method and Materials}

The focus carried out in this study was to build a mobile-based clean water ordering application design using the user-centered design method. The stages carried out in this study are preceded by the requirements data stage, followed by creating a design interface. After the interface design has been designed, the next step is to make a prototype design. This prototype's entire system involves several respondents from the customer and the service provider to evaluate the prototype design to obtain results according to the user's wishes and needs. The next stage is designing applications based on the previous prototype design. This application design also involves respondents evaluating all design interfaces made according to users' wants and needs both from the consumer and the service provider. If the user needs are fulfilled, then the last stage is where the proposed system design will be analyzed whether the system design acceptable or not based on the size of the user-centered design perspective. The framework of these stages can be seen in figure 1 . 


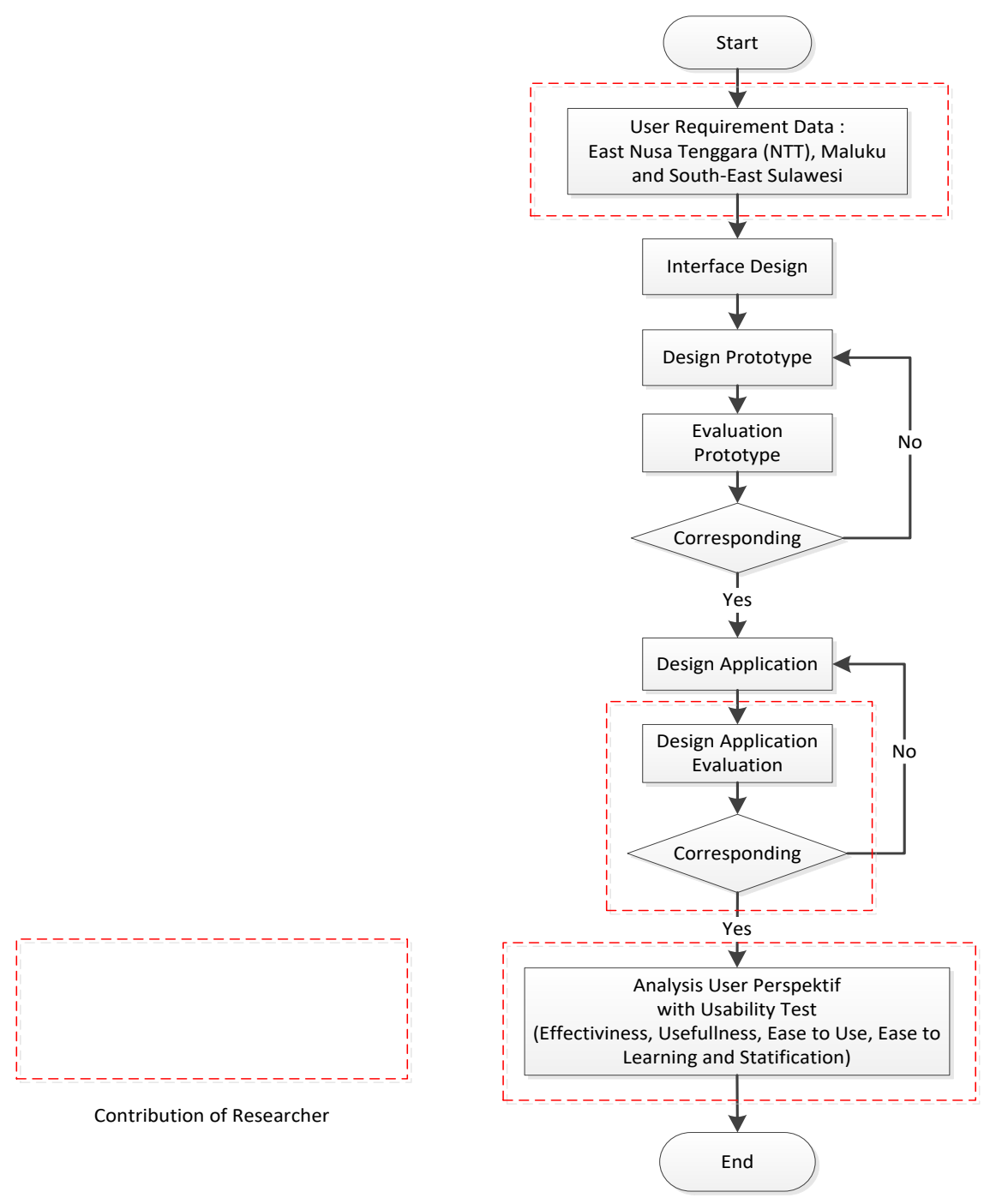

Fig. 1. Research Flow Diagram

In this study, based on the results of a field study analysis, it was found that the prices offered by service providers, both long-distance and short distance, were relatively the same. The service provider has not calculated the fuel cost, the price of filling the water tank, and the gap between the driver's position and the customer's location. The price makes service providers unable to get maximum profit. Hence, researchers offer a price system by calculating between a distance of IDR 5,000 with capital issued by drivers as in table 1 and selling tank water prices to consumers, as shown in table 2 . 
Table 1. Driver Expenses

\begin{tabular}{|c|l|c|}
\hline No. & \multicolumn{1}{|c|}{ Driver Capital } & Price \\
\hline 1. & Fuel (Bio Solar) & IDR 9,800/Liter \\
\hline 2. & Filling the Water Tank 5,000 Liter & IDR 10,000 \\
\hline 3. & Filling the Water Tank 6,000 Liter & IDR 12,000 \\
\hline
\end{tabular}

Table 2. The Price of Selling Clean Water

\begin{tabular}{|c|l|c|}
\hline No. & \multicolumn{1}{|c|}{ Sale } & Price \\
\hline 1. & Car Tank 5,000 Liter & IDR 65,000 \\
\hline 2. & Car Tank 6,000 Liter & IDR 75,000 \\
\hline
\end{tabular}

A formula for the proposed system is

profit $=($ car tank + distance per kilometer $)-\left(\right.$ filling the water tank $\left.+\left(\frac{f u e l}{2}\right)\right)$

Formula (1) shows that the car tank is the price of the tank car's capacity model sold to the consumer and distance per kilometer, namely the millimeter's travel price from the drive location to the consumer. The fuel used by the portable tank and divider number 2 is the researcher's number based on fuel consumption from the clean water tank 1 to 2 .

For example, use formula (1). Consumers order clean water from service providers with a tank capacity of 5,000 liters with a distance between consumers and drivers as far as 0.7 kilometers are charged at IDR 70,000. Thus, the benefits obtained from the driver are calculated using the count as in the calculation (2)

$$
\begin{gathered}
\text { profit }=(65,000+5,000)-\left(10,000+\left(\frac{9,800}{2}\right)\right) \\
\text { profit }=55,100
\end{gathered}
$$

Based on the calculation results (2), the profit obtained by the driver is IDR 55,100.

\subsection{Requirement data}

In this study, two stages are passed to get user needs: literature studies and field studies. In the literature study phase, the researchers collected several previous studies from various sources such as paper, internet, books, and other sources. Then at the field study stage, researchers collected information from users of clean water ordering services and service providers through direct interviews in three provinces, namely: East Nusa Tenggara, Moluccas, and Southeast Sulawesi.

\subsection{Stage of needs analysis}

This stage will analyze user needs based on user characteristics to build a design for ordering clean water applications using the UCD process steps, as shown in figure 2 . 


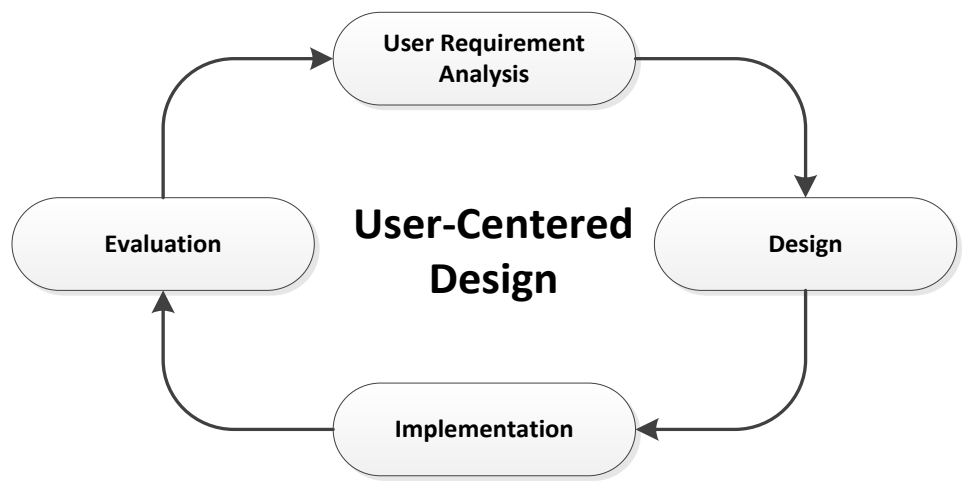

Fig. 2. UCD Process [25]

Plan interface design based on user needs: At this stage, interface design planning will be carried out based on user needs from information obtained when interviewing service providers and users of ordering water services from three places, namely the NTT, Moluccas, and Southeast Sulawesi provinces.

Determine user specifications: At this stage, the user specifications are determined by looking at the field's criteria, among others, based on age, gender, occupation, location, and ability to operate a smartphone.

Build an interface design: At this stage, the UCD cycle process will be implemented. Making the first interface design continues with the prototype up to the application design based on user requirements will be evaluated. The cycle will continue if user needs are not met. Conversely, if the user needs are met, the UCD cycle process will stop.

Perspective user analysis: This stage will be carried out usability testing on the design of clean water ordering applications. Usability tests that will be carried out cover effectiveness, usefulness, ease of use, ease of learning, and stratification. The function of a usability test is to measure the success rate of the application being built.

\subsection{Prototype design}

From the results of the analysis, several needs were obtained. The Go-Water prototype design was presented by adjusting the community's water reservoir model in the three places. People as water ordering services have two water storage models, namely water tendons with 5300 liters. There are also models of reservoirs built by the community with an average size of 5000 liters to 6000 liters. The prototype interface design, such as figure 3 shows the home page, is adjusted to the model and capacity of water storage in the community.

The clean water service providers in these three places have an average capacity of 5000 liters of tank cars and 6000 liters. So, customers will be made easier when they have chosen the model and reservoir capacity, which will then display a list of drivers, as shown in figure 4 , which is currently available for ordering by customers. 
Customers are still minimal information about drivers obtained. The old system's price has not been maximized because it traveled from the driver's location to the consumers' place (service users). Thus, the system offered will display driver information and price information calculated based on the distance between drivers and consumers in detail, as shown in figure 5.

Often, clean water ordering service providers find it challenging to find consumers' locations to distribute clean water becomes longer. Thus, the interface system offered users a map navigation path based on the global positioning system (GPS), as shown in figure 6 . The course will provide the fastest route to providers of clean water services (drivers) for distribution to consumers.

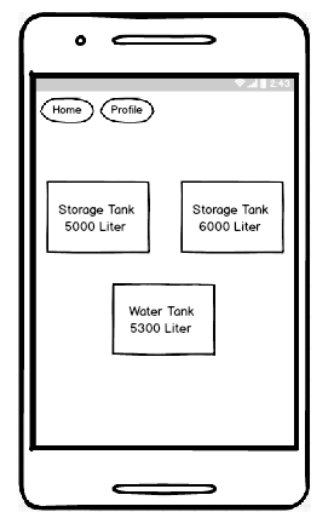

Fig. 3. Home Page

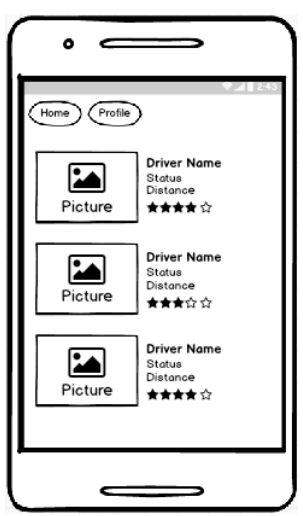

Fig. 4. Driver List 


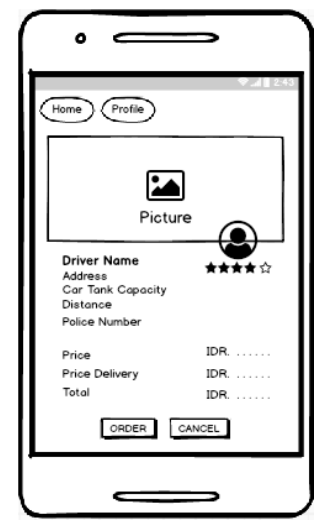

Fig. 5. Driver Details

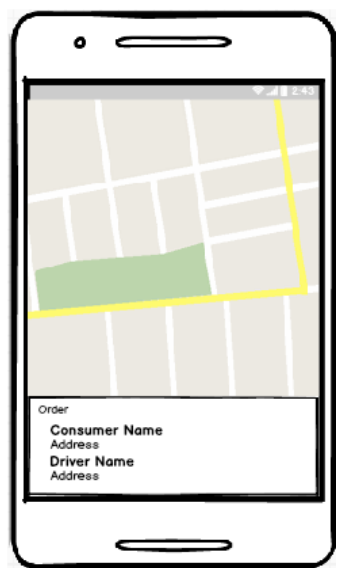

Fig. 6. Navigator Map for Consumers

Information on profile data is needed by both parties to make it easier to carry out communication interactions telephone and message. Thus, the design of the system interface prototype offered to both parties is a prototype interface design that can store and update each profile, such as in figure 7 and figure 8 .

Consumers and service providers need notifications in supporting the process of distributing clean water. The information being traced is more accurate; drivers will provide conditions for freshwater availability to be distributed, as shown in figure 9. And consumers will be more explicit about the availability of clean water available to service providers, as shown in figure 4 . If the customer orders clean water for the selected driver, the notification will be displayed on the driver's system interface, as shown in figure 10 . 


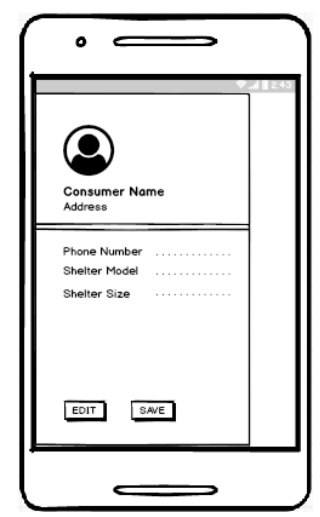

Fig. 7. Consumer Profile

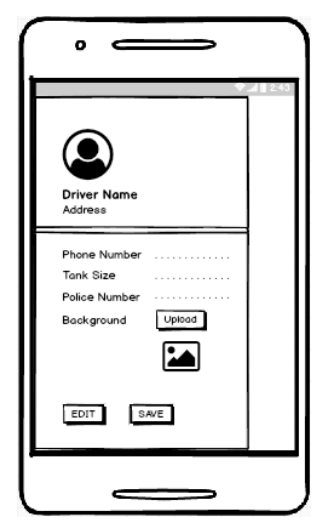

Fig. 8. Driver Profile

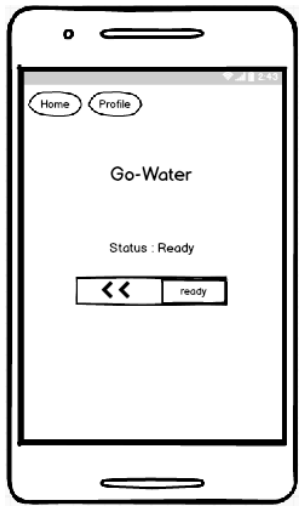

Fig. 9. Conditions for Availability of Water 


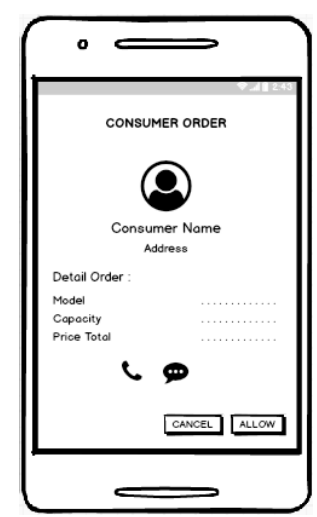

Fig. 10.Order Details

In the old system, the driver's position when delivering clean water is not obtained in real-time so that the customer does not seem to know when the driver arrives at the customer's place. The customer's system interface is the customer who knows the driver's position who is sending clean water in real-time, as shown in figure 11.

To complete the entire process of ordering clean water that has been carried out on the system offered, the driver will complete the order on the course, as shown in figure 6. All information on the payment of clean water will be displayed to the customer indicated in figure 12. In addition to payment information, customers can also assess services offered by service providers (drivers).

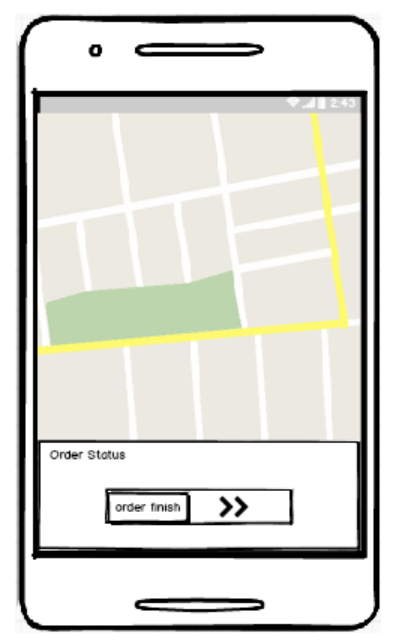

Fig. 11.Navigator Map for Driver 


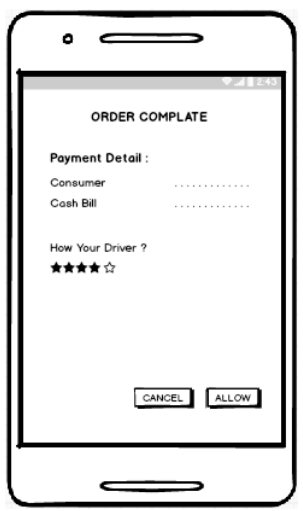

Fig. 12.Bill Payment

\subsection{Questionnaire}

To analyze the proposed system design results, whether it is following user needs based on the user-centered design measurement, the questionnaire questions are distributed to respondents to get it back to conclude in this study. These questions are relevant to the system design interface and perceived usefulness, as in table 3 .

Table 3. Questionnaire Table

\begin{tabular}{|c|c|c|c|c|c|c|}
\hline \multirow{2}{*}{ No. } & \multirow{2}{*}{ Question } & \multicolumn{5}{|c|}{ Description } \\
\hline & & $S D$ & $D$ & $L D$ & $A$ & $S A$ \\
\hline 1. & Q1: This Go-Water application helps users to order water. & & & & & \\
\hline 2. & Q2: The Go-Water application is built according to user needs. & & & & & \\
\hline 3. & Q3: The Go-Water application that is built is easy to use by users. & & & & & \\
\hline 4. & Q4: The facilities owned by the Go-Water application are sufficient. & & & & & \\
\hline 5. & $\begin{array}{l}\text { Q5: The Go-Water application that is built has a menu display that is easily } \\
\text { understood by users. }\end{array}$ & & & & & \\
\hline 6. & $\begin{array}{l}\text { Q6: The Go-Water application built has features and navigation buttons that } \\
\text { follow the user's wishes. }\end{array}$ & & & & & \\
\hline 7. & $\begin{array}{l}\text { Q7: The color combination of the Go-Water application display is built accord- } \\
\text { ingly and is comfortable to use. }\end{array}$ & & & & & \\
\hline 8. & $\begin{array}{l}\text { Q8: The font types found on the Go-Water application are suitable and comfort- } \\
\text { able for the user. }\end{array}$ & & & & & \\
\hline 9. & $\begin{array}{l}\text { Q9: The font size found on the Go-Water application is suitable and comfortable } \\
\text { for the user. }\end{array}$ & & & & & \\
\hline 10. & Q10: The Go-Water application that is built is useful for users. & & & & & \\
\hline
\end{tabular}

Table 3 shows ten questions given to respondents to consumers or drivers as water supply ordering services in the three provinces. The ten questions use the 5 Likert scale answer format, namely strongly disagree (SD), disagree (D), less disagree (LD), agree (A), and strongly agree (SA). 


\subsection{Sequence diagram of application}

The concept of the clean water ordering system proposed in this study is described systematically in two sequence diagrams, namely sequence diagrams for the display of consumers and sequence diagrams for display in the drivers contained in figure 13 and figure 14.

In the consumer interface sequence diagram in Figure 13, the first interface displayed to the consumer is the home page, as shown in figure 3. Consumers can place an order by selecting one of the three shelter models that are owned, as in figure 3 . After the consumer chooses one of the water storage models, the consumer will then select the list drivers, as shown in figure 4. Information about the driver and price details are displayed to the consumer before making an order, as shown in figure 5. If the consumer agrees to order, the request will be forwarded to the driver for confirmation.

Furthermore, the driver position will be displayed in the navigation map on the consumer, as shown in figure 11, until the driver completes the order process. Payment receipts will be presented, as shown in figure 12. After the driver receives payment from the consumer and completes the entire distribution process of clean water. In addition to the ordering process, consumers can also make personal information changes, as shown in figure 7.

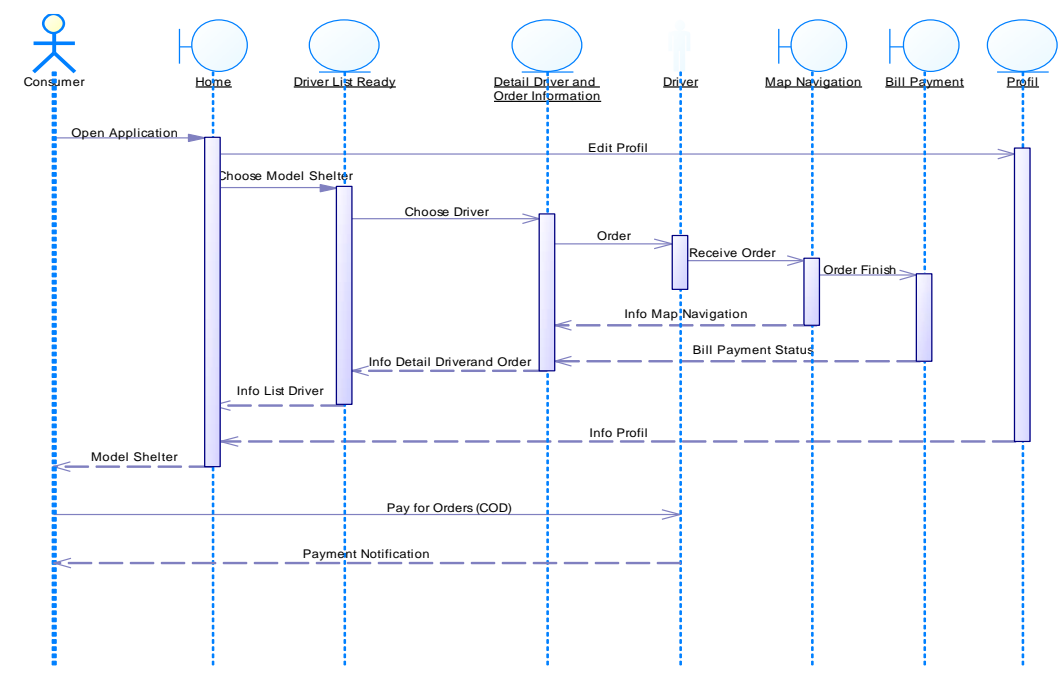

Fig. 13. Consumer Sequence Diagram

In the driver interface diagram in Figure 14, the first interface displayed in the driver is the interface information on the status of the water availability, as shown in figure 9, which is filled in the driver's tank car. The next process is carried out after the customer places an order, and the driver will receive a notification of the order and do the order process, as shown in figure 10. Then the navigation map is displayed for the driver, as shown in figure 6 . The driver will complete the entire order process 
when the driver completes the whole clean water distribution process and receives payment from the consumer after selecting the order finish button, as shown in figure 6. As with the consumer interface, drivers can also make changes to the data profile, as shown in figure 8 .

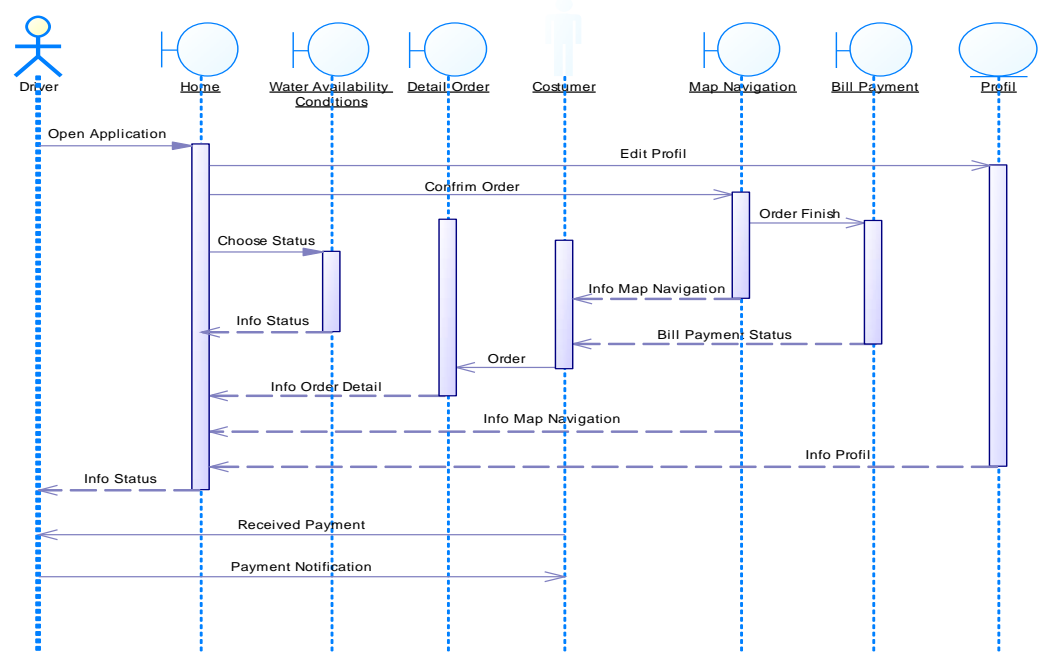

Fig. 14. Driver Sequence Diagram

\section{$4 \quad$ Result and Discussion}

At this stage, the final prototype system and design were successfully created based on user perception results, both in terms of interface design and system usability. Two parts of user perception will be explained in this chapter: interface design and usability testing.

\subsection{Interface design}

The results of taking user needs from the prototype design for the Go-Water clean water ordering application have resulted in several interface design evaluations being applied to the Go-Water application design. The Go-Water use's final interface design can be seen in figure 15 is the home page design that is added to the model icon of the water reservoir following the size of each. The menu bar is added to the home icon and profile. Figure 16 and figure 17 do not have a significant change from the prototype's design. Figure 18 shows the Go-Water application design changes are not substantial; only the map-marker icon is added to the display of the consumer order and the car icon in the driver.

Whereas in figure 19 and figure 20, there is no change in the prototype's appearance, it's just added color that matches the water itself's representation. Figure 21 shows the additions are made only to the Go-Water application's logo. There are no 
changes for the other designs but only the addition of colors and the home and profile icon. While the interface design for figure 22 has no change in the design structure, only in color design.

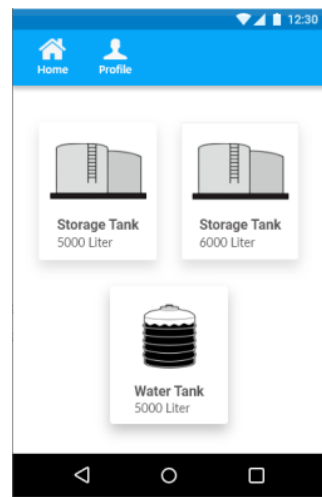

Fig. 15.Design of Home Page

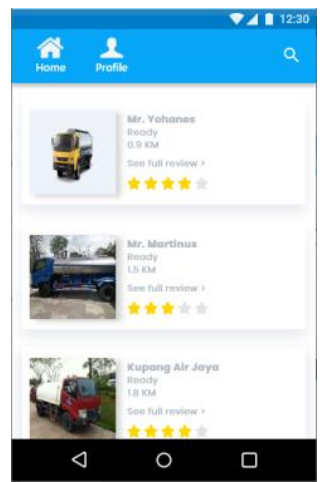

Fig. 16.Design of Driver List

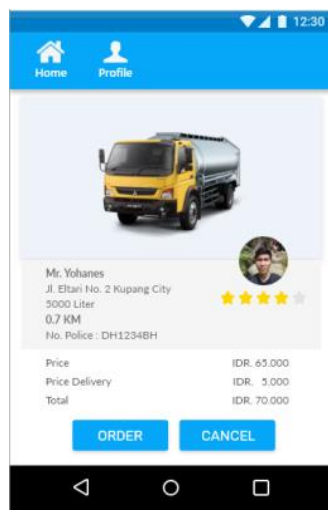

Fig. 17.Design of Driver Details 


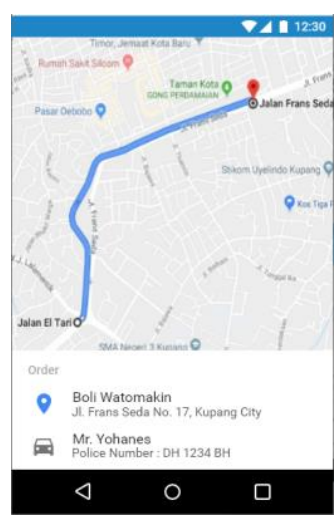

Fig. 18.Design of Navigator Map for Consumers

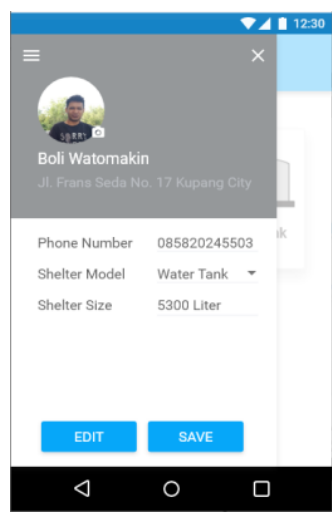

Fig. 19.Design of Consumer Profile

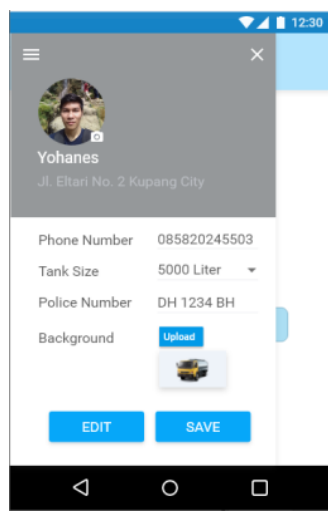

Fig. 20.Design of Driver Profile 


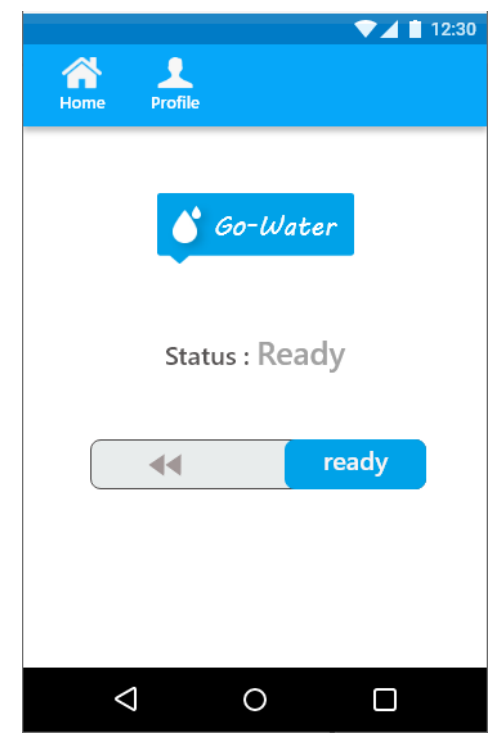

Fig. 21.Design of Conditions for Availability of Water

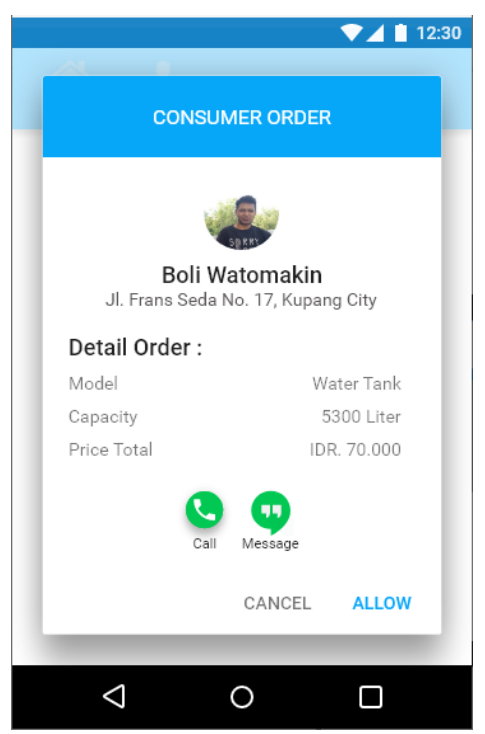

Fig. 22.Design of Order Details

Figure 23 shows that the driver navigator map is also the same as figure 22, which has no change. Figure 24 shows the differences found in the colors and reports in the form of pop-up notifications. While for others, there is no change in the interface design from the previous prototype design. 


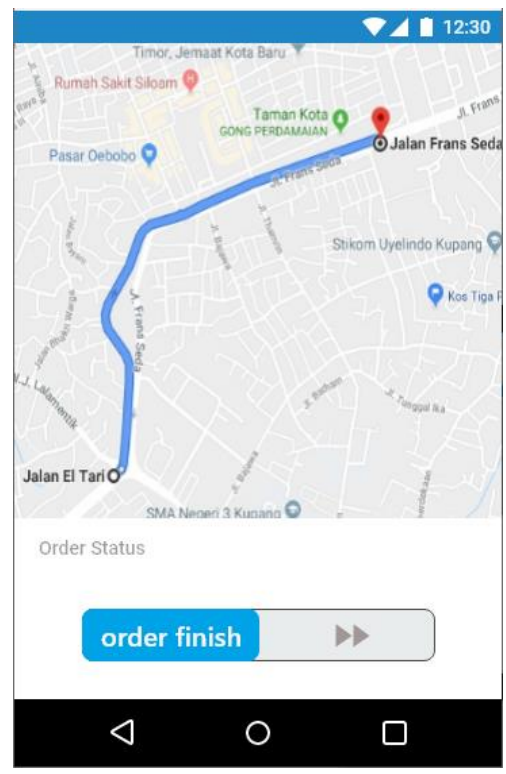

Fig. 23.Design of Navigator Map for Driver

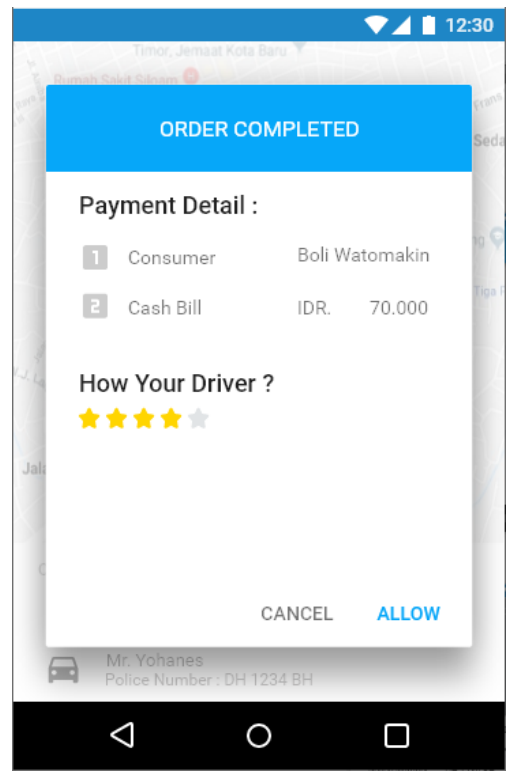

Fig. 24.Design of Bill Payment

All interface designs described have gone through the entire cycle process in the UCD method, where interface as the whole system meets users' needs in terms of ordering clean water using a tank car. 


\subsection{Usability test}

Evaluation of application designs that have been passed and approved by following the circle process in the UCD method, then conducted a usability test perspective analysis using a questionnaire with ten randomly distributed questions in three provinces, which became the case studies of this study. Table 4 shows the result of the survey distributed has received a response as much as 116 respondents.

Table 4. Summary of Usability Test

\begin{tabular}{|c|c|c|}
\hline No. & Question & Percent \\
\hline 1. & Q1 & $86 \%$ \\
\hline 2. & Q2 & $84 \%$ \\
\hline 3. & Q3 & $84 \%$ \\
\hline 4. & Q4 & $80 \%$ \\
\hline 5. & Q5 & $82 \%$ \\
\hline 6. & Q6 & $82 \%$ \\
\hline 7. & Q7 & $82 \%$ \\
\hline 8. & Q8 & $82 \%$ \\
\hline 9. & Q9 & $82 \%$ \\
\hline 10. & Q10 & $84 \%$ \\
\hline \multicolumn{2}{|r}{ Overall average percentage } & $83 \%$ \\
\hline
\end{tabular}

Table 4 shows each questionnaire question's calculation results using calculations (3) to get a percentage of each item.

$$
\text { Index formula } \%=\frac{\text { Total Score }}{Y \times 100}
$$

The total score is the highest (of the answer) multiplied by the number of respondents (who provide feedback). For Y, multiplication between the most elevated score multiplied by $100 \%$ so that each question's average score value is obtained [26]. Then, the total percentage of each item will be in the average number of all things, resulting in $83 \%$, as in table 4.

\section{Conclusion}

The design of mobile water-based ordering applications using mobile cars using the UCD method has been completed. Based on the results and discussions conducted, this system is easy to use by consumers and drivers as users of services using the GoWater application. This system follows its function and has met users' needs to clean water through the Go-Water form. The results have been analyzed using the five variable usability tests, as in table 4 , which yields an average value of $83 \%$. Thus, it shows that this research has successfully designed mobile water-based ordering application designs suitable for the user's needs.

In this research, there are three points as our contributions, namely: 
- Design of mobile applications for ordering clean water built in a center for users (UCD).

- There is no cellular application system for ordering clean water using tank cars and with a capacity of 5,000 liters and 6,000 liters.

- The price offered is more beneficial for both parties, both as service providers and service users.

\section{$6 \quad$ References}

[1] J. J. Messakh, D. L. Moy, D. Mojo, and Y. Maliti, “The linkage between household water consumption and rainfall in the semi-arid region of East Nusa Tenggara, Indonesia," in IOP Conference Series: Earth and Environmental Science, 2018, vol. 106, no. 1. https:// doi.org/10.1088/1755-1315/106/1/012084

[2] Kemenpu, Statistical Information Book. Ministry of Public Works and Public Housing, Data and Information Technology Center (PUSDATIN), 2017.

[3] W. Wardiha, Made and A. Putri, Pradwi, Sukma, "Mapping Water Supply Issues in the Province of East Nusa Tenggara with a System Interrelationship Model," Balai Pengemb. Teknol. Perumah. Tradis. Denpasar, vol. 6, no. 2, p. 7, 2016.

[4] Hootsuite, "Digital 2019 Indonesia," 2019. [Online]. Available: https://datareportal.com/ reports/digital-2019-indonesia [Accessed: 24-Apr-2019].

[5] B. Sedlmayr, J. Schöffler, H. U. Prokosch, and M. Sedlmayr, "User-centered design of a mobile medication management," Informatics Heal. Soc. Care, vol. 44, no. 2, pp. 152-163, 2019. https://doi.org/10.1080/17538157.2018.1437042

[6] S. Atawneh, B. Al-Kasasbeh, and M. Ben Rshed, "Android-based Mobile Application for Door-to-Door Product Delivery,” Int. J. Interact. Mob. Technol., vol. 13, no. 03, p. 125, 2019. https://doi.org/10.3991/ijim.v12i7.9598

[7] S. Duraisamy and J. U. Abuhuraira, "Android Mobile Application for Online Bus Booking System,” Int. J. Inf. Syst. Enginering, vol. 6, no. July, pp. 34-56, 2018.

[8] D. M. N. Abdullah and E. H. Kadhim, “Airline Mobile Reservation Development," Iarjset, vol. 3, no. 10, pp. 1-3, 2016.

[9] H. T. Roy Deddy, "A Food Ordering System with Delivery Routing Optimization Using Global Positioning System (GPS) Technology and Google Maps," Internetworking Indones. J., vol. 8, no. January 2016, pp. 3-8, 2016.

[10] X. Zhang and J. Bi, "Design of a college English mobile learning system based on CAD model,” Int. J. Emerg. Technol. Learn., vol. 13, no. 4, pp. 139-149, 2018. https://doi.org/ 10.3991/ijet.v13i04.8477

[11] M. Computing, W. D. Raharjo, and A. Wardhana, "an Analysis of Design Android Food Ordering Applications at Taichan Kumis Restaurant,” Int. J. Comput. Sci. Mob. Comput., vol. 7, no. 6, pp. 94-108, 2018.

[12] N. Jochems, "Designing Tablet Computers for the Elderly A User-Centred Design Approach," in International Conference on Human Aspects of IT for the Aged Population, 2016, vol. 9754, pp. 42-51. https://doi.org/10.1007/978-3-319-39943-0_5 
[13] M. Larusdottir, V. Roto, J. Stage, and A. Lucero, "Get Realistic! - UCD Course Design and Evaluation," in International Working Conference on Human-Centred Software Engineering, 2019, vol. 11262, pp. 15-30. https://doi.org/10.1007/978-3-030-05909-5_2

[14] R. Schnall et al., "A user-centred model for designing consumer mobile health (mHealth) applications (apps),” J. Biomed. Inform., vol. 60, pp. 243-251, 2016.

[15] M. Maher et al., "User-Centred Design Groups to Engage Patients and Caregivers with a Personalized Health Information Technology Tool," Biol. Blood Marrow Transplant., vol. 22, no. 2, pp. 349-358, 2016. https://doi.org/10.1016/j.bbmt.2015.08.032

[16] L. Runaas et al., "BMT Roadmap: A User-Centred Design Health Information Technology Tool to Promote Patient-Centred Care in Pediatric Hematopoietic Cell Transplantation," Biol. Blood Marrow Transplant., vol. 23, no. 5, pp. 813-819, 2017. https://doi.org/10.1016 lj.bbmt.2017.01.080

[17] G. Tanaksaranond, "The Development of a Mobile Map Application for Park and Ride Users,” Int. J. GEOMATE, vol. 15, no. 49, pp. 143-149, 2018. https://doi.org/10.21660/ 2018.49.sgi176

[18] Muljono, G. W. Saraswati, N. A. S. Winarsih, N. Rokhman, C. Supriyanto, and Pujiono, "Developing BacaBicara: An Indonesian lipreading system as an independent communication learning for the deaf and hard-of-hearing," Int. J. Emerg. Technol. Learn., vol. 14, no. 4, pp. 44-57, 2019. https://doi.org/10.3991/ijet.v14i04.9578

[19] P. W. T. Maharani Maulydia, Arianis Chan, "Comparison of User Experience on Go-Jek and Grab Mobile Apps (A Study on PT. Go-Jek and PT. Grab Indonesia Consumers in DKI Jakarta)," in Parahyangan International Accounting and Business Conference, 2017, pp. 14-30. https://doi.org/10.24198/adbispreneur.v2i2.13183

[20] L. A. Wardana, S., and P., "Design Mobile Application of Marriage Counselling on the Catholic Church with UCD and Wireframe Method," Int. J. u- e- Serv. Sci. Technol., vol. 10, no. 1, pp. 153-162, 2017. https://doi.org/10.14257/ijunesst.2017.10.1.13

[21] P. Zaphiris and A. Ioannou, "Assessments of User Centred Design Framework for mlearning Application Development," in the 15th International Conference on HumanComputer Interaction, 2015, vol. 9192, no. April.

[22] R. Dermawi, H. Tolle, and I. Aknuranda, "Design and Usability Evaluation of Communication Board for Deaf People with User-Centred Design Approach,” Int. J. Interact. Mob. Technol., vol. 12, no. 2, p. 197, 2018. https://doi.org/10.3991/ijim.v12i2.8100

[23] R. Roth, K. Ross, and A. MacEachren, "User-Centred Design for Interactive Maps: A Case Study in Crime Analysis,” ISPRS Int. J. Geo-Information, vol. 4, no. 1, pp. 262-301, 2015. https://doi.org/10.3390/ijgi4010262

[24] Y. Arifin, M. Martin, R. Ryan, and R. Dratama, "Gamification for the Ancient Kingdom of Nusantara with User-Centred Design Approach," ComTech Comput. Math. Eng. Appl., vol. 9, no. 1, p. 9, 2019. https://doi.org/10.21512/comtech.v9i1.4171

[25] R. Risald, S. Suyoto, and A. J. Santoso, "Mobile Application Design Emergency Medical Call for the Deaf using UCD Method," Int. J. Interact. Mob. Technol., vol. 12, no. 3, p. 168, 2018. https://doi.org/10.3991/ijim.v12i3.8754

[26] D. Turmudi, "The Affecting Factors Addressed in Efl Essay Class of Um Metro Lampung in Respect to the Students' Perception and the Lecturer'S Reflection," PREMISE JOURNALISSN online 2442-482x, ISSN Print. 2089-3345, vol. 3, no. 1, pp. 1-17, 2017. https://doi.org/10.24127/pj.v3i1.693 


\section{$7 \quad$ Authors}

Dominikus Boli Watomakin is a Master of Informatics Engineering Student at Universitas Atma Jaya Yogyakarta, Yogyakarta, Indonesia. He is a scholar of the Stikom Uyelindo Kupang. His research interests are the mobile app, and user interface design.

Baltra Agusti Pramajuri is a Master of Informatics Engineering Student at Universitas Atma Jaya Yogyakarta, Yogyakarta, Indonesia. He is a scholar of the STMIK Amikom Yogyakarta. His research interests are the mobile app, Internet of Things (IoT) and user interface design.

Suyoto is Professor in Department of Informatics Engineering at Universitas Atma Jaya Yogyakarta, Yogyakarta, Indonesia. He has more than nineteen years of teaching experience. He received his $\mathrm{PhD}$ in 2000 from the National University of Malaysia, Malaysia. His research interests are multimedia, computer graphics, visualization, mobile application and artificial intelligence.

Article submitted 2019-07-16. Resubmitted 2019-11-26. Final acceptance 2020-11-27. Final version published as submitted by the authors. 